\title{
Assessing Vegetation Heritage Value: The Alentejo Central (Portugal) as a Case Study
}

\author{
Teresa Batista ${ }^{1, *}$, José Manuel de Mascarenhas ${ }^{2}$, Paula Mendes ${ }^{3}$ and Carlos Pinto-Gomes ${ }^{4,5}$ (D) \\ 1 MED—Mediterranean Institute for Agriculture, Environment and Development, Institute for Advanced \\ Studies and Research, University of Évora, Pólo da Mitra, Ap. 94, 7006-554 Évora, Portugal \\ 2 CIDEHUS-Interdisciplinary Centre for History, Culture and Societies of University of Évora, \\ Palácio of Vimioso, Largo do Marquês de Marialva, n. ${ }^{\circ}$ 8, Apartado 94, 7000-809 Évora, Portugal; \\ mascarenhas_jm@outlook.pt or cidehus@uevora.pt \\ 3 Institute for Nature Conservation and Forestry, Regional Direction of Alentejo. R. Tenente Raul de Andrade, \\ 1 e 3, 7000-613 Évora, Portugal; paula.mendes@icnf.pt \\ 4 MED-Mediterranean Institute for Agriculture, Environment and Development \& Department of Landscape, \\ Environment and Land Planning, School of Science and Technology, University of Évora, Ap. 94, 7006-554 \\ Évora, Portugal; cpgomes@uevora.pt \\ 5 Institute of Earth Sciences (ICT), School of Science and Technology, University of Évora, Rua Romão Ramalho, \\ $\mathrm{n}^{\circ}$ 59, 7000-671 Évora, Portugal \\ * Correspondence: mtfb@uevora.pt
}

Citation: Batista, T.; de Mascarenhas, J.M.; Mendes, P.; Pinto-Gomes, C. Assessing Vegetation Heritage Value: The Alentejo Central (Portugal) as a Case Study. Land 2021, 10, 307. https://doi.org/10.3390/land10030307

Academic Editor: Robert Baldwin

Received: 19 January 2021

Accepted: 6 March 2021

Published: 17 March 2021

Publisher's Note: MDPI stays neutral with regard to jurisdictional claims in published maps and institutional affiliations.

Copyright: (c) 2021 by the authors. Licensee MDPI, Basel, Switzerland. This article is an open access article distributed under the terms and conditions of the Creative Commons Attribution (CC BY) license (https:// creativecommons.org/licenses/by/ $4.0 /)$.

\begin{abstract}
Vegetation natural heritage can be valued in itself, but also as a habitat for many wildlife species. This study presents a methodological essay concerning the evaluation of plant heritage, applied in Central Alentejo, in the south of Portugal. This evaluation was based on the following criteria: horizontal and vertical structure of vegetation, tree cover density, rare plant species richness, phytocenotic maturity, importance as ecological corridor, historical record, scientific and educational potential and recreational potential. The vegetation heritage value (VHV) was calculated using a linear combination of the weighted criteria. In this way it was possible to identify the most interesting areas for conservation purposes. Of the $7500 \mathrm{~km}^{2}$ analyzed, $52 \%$ are natural and semi-natural areas, and of these, $18.8 \%$ have very high VHV, $70.7 \%$ have high VHV and only $10.5 \%$ average VHV. The highest VHV areas are actually included under the protected areas of Natura 2000 sites.
\end{abstract}

Keywords: vegetation heritage value; estimation methodology; landscape heritage; landscape ecology and planning; southern Portugal

\section{Introduction}

In the general concept of heritage, the emphasis on inherited goods and their conservation is important, generally encompassing elements, places and practices that have meaning in the present and that relate to the past. In the classification of heritage, it is common to make a distinction between cultural heritage [1] and natural heritage [2,3]. The first concept involves man-made artifacts and other aspects related to "culture", some of which are of an intangible nature; the second one, concerns elements not manufactured by humans. However, in practice, heritage is a very complex concept, in which the two components, cultural and natural, are closely linked [4], with many of its values being of a bio-cultural nature, translating an interpenetration between the two domains. In relation to the natural heritage, it must be approached as a gift of nature, being composed of biotic and abiotic natural elements. Concerning its intrinsic aspects, it is mainly valued for its contribution to ecological, biological and geological processes and the relative importance of natural habitats for the conservation of biodiversity.

The extension of the concept of heritage to the natural environment occurred since at least the middle of last century. The acceptance of this extension at the international level took place mainly following the Convention for the Protection of the World Cultural and 
Natural Heritage [3], adopted by the General Conference of UNESCO on 16 November 1972. It was then considered that the natural heritage included relevant biotic and abiotic elements as well as natural sites.

This was an important step in the concept of heritage which should not only be characterized, but also monitored and managed in everyday life, becoming recognized in its living and evolutionary aspect [5].

Although that Convention has been subject to periodic reviews since its first edition, a more integrated approach to natural and cultural heritage has not been envisaged so far. The fact that in Article 2 of the Convention, which addresses the natural heritage, there is no mention of combinations of natural and cultural elements, or of the interaction between Man and the Environment [6], led many countries to create 'separate policies for natural and cultural heritage conservation, including different administrations that apply different legislation, methods, languages, scientific disciplines, and practices' [7].This does not invalidate the option in this paper by conducting a methodological development essay to estimate the natural heritage, addressing this per se and in an intrinsic way, which is considered of interest in the framework of the management of the conservation of natural vegetation.

Among the different factors used to estimate landscape heritage, vegetation is one of the most important, however it is missing an integrated methodology for its evaluation.

For several years, the authors have been carrying out studies on the surrounding landscape of the city of Évora and other areas of Alentejo (southern Portugal), developing methods aimed at calculating the value of natural, cultural and landscape heritage.

This paper presents an essay on an integrated methodology developed to estimate the Vegetation Heritage Value (VHV), and as a case study, its application to the Central Alentejo (NUT III), an area of $7500 \mathrm{~km}^{2}$, with Mediterranean characteristics, located in the south of Portugal.

There is a lack of research concerning practical and objective methods for the assessment of vegetation heritage, so this study is not only a contribution to heritage scientific research but also to support landscape and land planning projects, as well as environmental impact assessment studies.

\subsection{The Montado as the Key Feature of Alentejo Central Landscape}

The Alentejo Central region is located in the south of Portugal and it has about $7500 \mathrm{~km}^{2}$. It is a typical area of Mediterranean vegetation in which a traditional land use system, the montado, occupies about $52 \%$ of the total area [8]. Montados are composed mainly of open formations of holm oaks (Quercus rotundifolia) and cork oaks (Qurecus suber) which have been managed for centuries in such a way that promotes biodiversity rather than reducing it. They are traditionally related to agro-silvo-pastoral systems in which a crop / fallow / pasture rotation occurs underneath the canopy of the referred quercus trees [9]. These montados are quite diverse in species, tree cover and structure, as it can be observed below, in Figure 1. One of the main characteristics of these traditional, multifunctional and bio-cultural landscapes is the persistence of the native vegetation scattered throughout the landscape, which gives rise to a heterogeneous mosaic, resulting not only from several agricultural uses, but also from a diverse tree, shrub and herbaceous cover, thus conferring diversity of composition and structure to the landscape. This complex formation produced one of the most aesthetically pleasing and biologically rich landscapes in Europe [10] (p. 100) and have high scientific and touristic interest.

Since 1999, the fundamental trees of montados (Quercus rotundifolia and Quercus suber) have been under legal protection (Decree-Law 140/99, dated 24 April-Annex B-1, republished by Decree-Law 49/2005, of 24 February; Directive 92/43/EEC, 21 May-Annex I Habitat 6310; Decree-Law 169/2001 of 25 May, with amendments; Decree-Law 155/04, of 30 June) and can be considered cultural heritage of high bio-cultural value. Cork and holm trees are along with olive trees the oldest trees in the Iberian Peninsula. Its wood 
is very strong and resistant and for this it was part of the raw material used to build the

Portuguese marine fleet during the Discoveries.

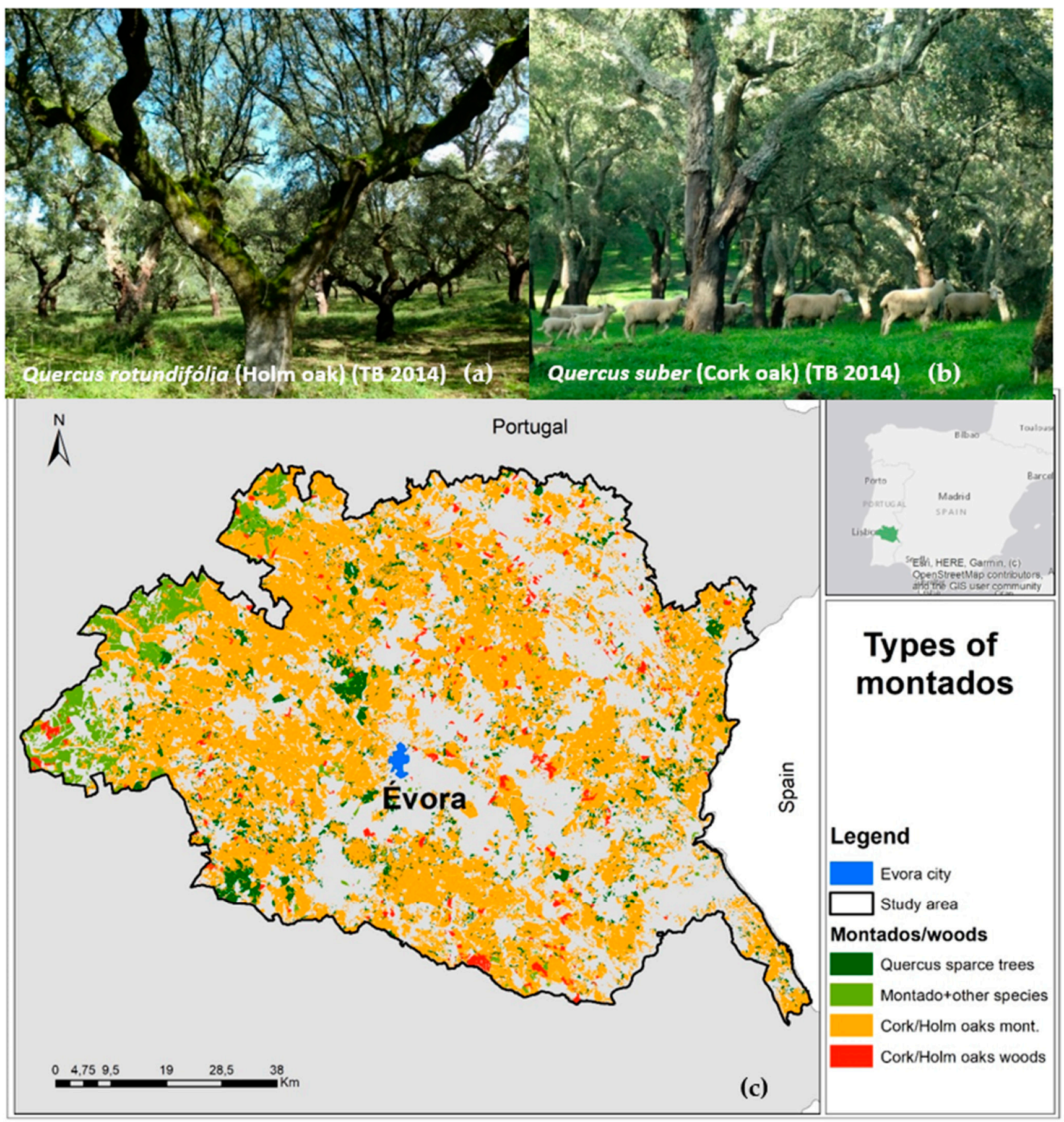

Figure 1. Study area and types of montados in Alentejo Central (author of photos (a,b) and map (c): T. Batista).

\subsection{Heritage Landscapes and Vegetation Heritage Value (VHV)}

Several types of values can be attributed to cultural landscapes, depending on the scientific approach of the experts or the modes of assigning stakeholders groups. Since heritage value is one of these types, the most valuable cultural landscapes can be designated as a heritage landscape. In other terms, the heritage landscape must then be considered as a cultural landscape of high patrimonial value [11]. As mentioned, vegetation should be regarded as an important factor, which conditions the value of landscape heritage and 
should be evaluated not only per se, but also as a habitat for many wild animal species. The heritage value of vegetation must, thus, be considered as a key factor in selecting the most interesting areas for the conservation of nature and vegetation in particular.

\section{Materials and Methods}

The model used for the estimation of the heritage value of the vegetation is based on the following criteria: evaluation of the horizontal and vertical structure of the vegetation patches and their importance as habitat, tree cover density, rare species richness, phytocoenosis maturity, importance as ecological corridor, historical record, scientific, educational and recreational potential.

These criteria were applied to the best-preserved vegetation patches, such as cork oak and holm oak montados, forests and woods, shrubs, meadows and marshes, vegetation corridors (river corridors mainly) including protected habitats and species with a conservation status. Agricultural and pastoral intensive areas were excluded from this analysis. The structure and composition of the vegetation were analyzed through the Corine Land Cover Map at the 1:10,000 scale elaborated by CIMAC-Intermunicipal Community of Alentejo Central, in 2008 [12]. This cartography is quite rich in information. It applies the Corine Land Cover Legend developed to the 1:10,000 scale (CLC5), with a 5 digits legend and 295 land use/land cover classes [13]. It also integrates field information such as the type of undercover vegetation and the percentage of tree canopy cover $(<10 \% ; 10-30 \% ; 30-50 \%$; $>50 \%$ ). It has a minimal cartographic unit of 0.5 hectares, and it was validated for land use and rare species through field surveys. An example of the CLC5 legend is presented bellow on Table 1.

Table 1. Extract from the legend Corine Land Cover level 5 (CLC5), details and number of patches analyzed.

\begin{tabular}{|c|c|c|c|c|}
\hline Code_CLC5 & Description & $\begin{array}{c}\text { Tree Density } \\
(\%)\end{array}$ & $\begin{array}{c}\text { Details in Undercover } \\
\text { Vegetation }\end{array}$ & $\begin{array}{c}\text { Number of } \\
\text { Patches Analyzed }\end{array}$ \\
\hline 3.1.1.1.2 & Holm oak woods & & & 75 \\
\hline 3.1.1.2.9 & Holm oak and Eucalyptus & & & 18 \\
\hline 3.1.1.2.10 & Holm oak and other broad-leaved trees & & & 7 \\
\hline 2.4.1.3.2 & Annual crops + Holm oak & & & 2251 \\
\hline 2.4.1.3.1 & Annual crops + Cork Oak & & & 775 \\
\hline 3.1.1.2.22 & Eucalyptus and Holm oak & & & 26 \\
\hline 3.1.1.2.21 & Eucalyptus and Cork oak & & & 25 \\
\hline 2.4.4.3.2 & Holm oak montado with permanent crops & & & 751 \\
\hline 2.4.4.2.2 & Holm oak montado with annual crops & & & 1035 \\
\hline 2.4.4.4.2 & Holm oak montado with shrubs & & Cistus spp. & 1774 \\
\hline 2.4.4.1.2 & Holm oak montado with pasture & & Olive trees & 6550 \\
\hline 2.4.4.3.1 & Cork oak montado with permanent crops & $(<10)$ & & 342 \\
\hline 2.4.4.2.1 & Cork oak montado with annual crops & $(10-30)$ & & 484 \\
\hline 2.4.4.4.1 & Cork oak montado with shrubs & $(30-50)$ & Cistus spp. & 942 \\
\hline 2.4.4.1.1 & Cork oak montado with pasture & $(>50)$ & & 2957 \\
\hline 2.4.4.2.3 & Mixed montado with annual crops & & & 169 \\
\hline 2.4.4.4.3 & Mixed montado with shrubs & & Cistus spp. & 637 \\
\hline 2.4.4.1.3 & Mixed montado with pasture & & & 2173 \\
\hline 3.1.1.2.27 & Holm oak and other broad-leaved trees & & & 1 \\
\hline 3.1.1.2.26 & Cork oak and other broad-leaved trees & & & 1 \\
\hline 3.1.3.1.8 & Resinous and Holm oak & & & 144 \\
\hline 3.1.3.1.7 & Resinous and Cork oak & & & 919 \\
\hline 3.1.1.1.1 & Cork oak wood & & & 629 \\
\hline 3.1.1.2.1 & Holm oak + Cork oak wood & & & 15 \\
\hline 3.1.1.2.4 & Cork oak and Eucalyptus & & & 37 \\
\hline \multirow[t]{2}{*}{ 3.1.1.2.5 } & Cork oak and other broad-leaved trees & & & 8 \\
\hline & & & Total & 22745 \\
\hline
\end{tabular}

Three or two evaluation classes were considered, depending on the nature of each criterion [14]. Using a general scale of values (convenience scale), a numerical value was 
assigned to each class, allowing the linear combination of the weighted criteria and the estimation of Vegetation Heritage Value (VHV) as following [11],

n

$$
\begin{gathered}
\mathrm{VHV}=\sum \mathrm{a}_{\mathrm{i}} \cdot \mathrm{X}_{\mathrm{i}} \\
\mathrm{i}=1
\end{gathered}
$$

( $n$-number of indicators; $a_{i}$-weighting coefficient; $X_{i}$-value assigned to indicator $i$ ).

For the selection of the weighting coefficients a relatively precise strategy was applied according to [14] and [15]. The definition of each criterion, as well as the corresponding weighting coefficient and number of evaluation classes are presented in the Section 2.3. Finally, the VHV was converted into a 0-100 scale. This methodology was applied to the Corine Land Cover Map of Alentejo Central region, at 1:10,000 scale, in a vectorial format, with a total of 22,745 analyzed patches. All the map algebra was undertaken with ArcMap GIS.

\subsection{Origin and Development of the Methodology}

The first known occurrence in which a heritage value was quantified through a weighted linear combination of estimated values of descriptors took place in the course of the Environmental Impact Assessment (EIA) of the Alqueva Dam Project, carried out between 1984 and 1987 [16]. This methodology was then applied not only to archaeological heritage [17] but also to vegetation heritage [18]. In this EIA, the vegetation, besides having been valued from the patrimonial point of view, was also analyzed in terms of functional value (as habitat of animal communities) and economic value [16].

Given the need to improve the method, with the introduction of new criteria, new studies were carried out within the framework of the activities of the University of Évora [19,20]. These studies, especially those related to the built heritage, were based on works by wellestablished authors, such as [21] (see particularly pp. 34-35), [22,23], and lately, [24,25], among others. As regards to the natural heritage, the analysis of the evaluation criteria has been supported mainly in [26-34]. It should be noted that this analysis sought to avoid the introduction of criteria that could create redundancy situations, which is why, for example, naturalness and wilderness were not considered. In order to evaluate the cultural landscape from the heritage point of view, it was necessary to consider new evaluation criteria $[11,14,35]$ the available bibliography being already very extensive, with a special emphasis on [24,36-42]. With the international acceptance of the concept of intangible heritage, special criteria extended to landscapes had to be introduced [43,44] and there is already a wide bibliographic database availability, such as [45,46], among others. Finally, as mentioned previously, in the development of this evaluation methodology, a strategy for selecting the weighting coefficients was defined, an aspect that is considered central to the feasibility of the method $[14,15]$.

\subsection{Potential Area for Vegetation Conservation Purposes}

As already mentioned, potential areas for vegetation conservation purposes were selected based on the estimation of the heritage value of the vegetation. This estimation was based on the use of several criteria, whose characterization is exposed as following:

\subsubsection{Horizontal and Vertical Structure-Importance as Habitat}

These criteria describe landscape patches through structural attributes of the ecosystem, related to their composition (internal heterogeneity), such as the height of different vegetation layers (vertical strata) and the complexity of the composition (horizontal patches).

The vertical structure diversity is related to the vertical distribution of the plants according to the three main levels: herbaceous, shrub and arboreal. It was classified according to the number of dominant vertical strata such as:

1 -Only one strata (herbaceous, shrubs, trees); 
2-Two strata (herbaceous + shrubs; herbaceous + trees);

3-Three strata (herbaceous + shrubs + trees).

The horizontal structural diversity refers to the number of dominant species in each vegetation patch given by the number of land cover types in a patch and it was classify such as:

1-One dominant specie;

2-Two dominant species;

3-Domain of three or more species.

The tree canopy density was also considered since it is an important factor on habitat quality as well as on the energy and nutrients fluxes. It influences for instant, the quality of woodland species habitat [43]. Tree canopy density refers to the density of the tree cover and it is classified into 3 classes according to the following tree density ranges:

1 -less than $10 \%$;

2-between 10 and $50 \%$;

3-more than 50 .

All these habitat characteristics are considered as habitat indicators, being important factors in the assessing of the potential of the area for conservation purposes.

\subsubsection{Vegetation Rarity}

According to [30], rarity is mostly a consequence of a confinement of species or communities to specific niches, or an adaptation to particular environmental conditions. It is therefore a natural characteristic of specific communities and their site conditions.

In the central region of Alentejo (southern Portugal) there are several Natura 2000 habitats, such as the montados (habitat 6310). In these ecosystems, one can find flora belonging to the Natura 2000 Annexes, such as Narcisus bulbucodium, Narcisus fernandesii, Ruscus aculeatus and Halimium verticillatum. In addition, as a result of continuous anthropogenic activity in this territory, different perennial grasses dominated by Poa bulbosa (habitat 6220 *) can be found in abundance. Dense pre-forested coverings (habitat 5330) are also important, including some restricted distribution subtypes, belonging to the thorny bushes of Calicotome villosa. In spite of the rare presence of climax forests, some cork oak (9330) and holm oak (9340) forests are present, and Ruscus aculeatus invariably appears under-cover [47,48]. Along the streams, three types of tree galleries are present, mainly consisting of: ash trees (91B0), alders (91E0) and willows (92A0), including some rare species such as Salix salviifolia subsp. australis.

In this study, the species rarity richness refers to the number of rare species with conservation status.

The areas where these rare species can be found are of great importance not only to the existing species conservation but also to maintain the flow of genes among them [30]. The protection of rare species and communities may act as an 'umbrella' for the biodiversity preservation in general.

\subsubsection{Phytocoenosis Maturity}

According to Merriam-Webster Unabridged Dictionary, phytocoenosis can be defined as the whole body of plants occupying a particular habitat. Phytocoenosis maturity degree is related with the distance of an ecosystem in its current form, to its assumed natural state in the total absence of human activity over time [30].

Our estimation of phytocoenosis maturity was based on the seral stage of the vegetation, which is related to the concept of succession, as defined by Eugene Odum. In his "maturity concept" this author postulated a general "strategy of ecosystem development", which is a well ordered process of community development resulting from changes in the physical environment caused by the ecosystem itself [49].

According to Frederick R. Gehlbach [50], "heritage value is a potentially important feature of natural areas, because it can be represented by climax communities (pre-settlement landscapes), the most stable nature provides". There is a close relationship between its 
heritage value criterion for evaluation of natural areas [50] (p. 84) and phytocoenotic maturity. This author estimates heritage value considering two classes: Late seral stage, and climax condition.

In this study, considering phytocoenosis maturity as the position of vegetation formation in the phytocoenotic series, three valuation classes were assumed, according to the distance to climax [51],

$$
\begin{aligned}
& \text { 1-young, } \\
& \text { 2-medium and } \\
& \text { 3-mature. }
\end{aligned}
$$

\subsubsection{Vegetation Corridors}

Ecological corridors are considered to be one of the most relevant characteristics of the landscape due to their important role in the connection between vegetation patches, reducing fragmentation and isolation, and favoring water, energy and material flows. Corridors are defined by Forman and Godron [52] as narrow strips of land which differ from the matrix on either side.

Hoechstetter [53] argues that corridors can be considered as a special type of spot: a 'longish' patch, which is separately considered because of its important functional role in landscapes. Corridors can also be defined according to their functional character-as narrow strips of habitat surrounded by habitat of other types [54].

Corridors are especially characterized by their connectivity over large distances and by environmental gradients between adjacent areas [52]. Corridors can be classified as: linear corridors (such as roads, hedges, property boundaries, drainage ditches and irrigation canals); strip corridors and river corridors (bordering waterways) [52].

Particularly important are vegetation corridors associated with habitats and connectivity. The most important corridors are the riparian ones, the hedges along walls and fences, and the road corridors. Such corridors may consist of trees, shrubs and herbaceous formations with varied compositions. In Mediterranean conditions riparian corridors are composed mainly of willow trees (Salix atrocinerea, Salix neotricha and Salix salvifolia subsp. australis), ash trees (Fraxinus angustifolia), alders (Alnus glutinosa), poplars (Populus nigra and Populus alba) and elm trees (Ulmus minor).

The effectiveness of ecological networks is greatly conditioned by vegetation corridors. An ecological network is defined by Bennett and Wit [55], as 'a coherent system of natural and/or semi-natural landscape elements that is configured and managed with the objective of maintaining or restoring ecological functions as a means to conserve biodiversity while also providing appropriate opportunities for the sustainable use of natural resources [56] (p. 8).

In this study, the importance of the ecological corridor criterion concerns the existence of flow corridors and their complexity and functional connectivity. In this study they were classified as following:

0 - no corridor present;

1 - existing corridor.

\subsubsection{Historical Record}

The historical record refers to the existence or not of historical research data. Using historic and recent vegetation records it is possible to study the vegetation change at several scales (local, regional or supra-regional) [31]. Vegetation, in terms of composition and structure, is closely related to past land use. Most of the present woods and montados occupy areas previously used by agriculture and pasturing, reflecting the potential vegetation and the processes of natural and human disturbance [57]. A long recorded history enhances educational and scientific values, and could also contribute to more effective management techniques [58].

Although this criterion has often been used since at least the 1980s [59], it is of relative interest as it does not correspond to an inherent feature of the site and it is difficult to be 
quantifiable. For these reasons it should be treated as an ancillary criterion [60] (p. 237). In this study, the vegetation formations were classified as following:

0 -low record;

1-high record.

\subsubsection{Scientific and Educational Potential}

This criterion mainly focuses on species and plant communities confined to specific niches, or adapted to specific environmental conditions, but also on those located in areas with a long history of land use that have often conditioned soil properties and diversity [30]. As the old forests are of great importance for the conservation of biodiversity, small fragments of such existing forests may constitute reservoirs for the propagation of relict species in younger formations [30].

Without questioning the importance of this criterion, its practical application becomes complex as it depends not only on the intrinsic interest of the vegetation, but also on the geographical location of the site, particularly with regard to ease of access and distance from the university or from the research center. For such reasons, it should be used as an ancillary criterion [60]. In this study, the vegetation formations were classified as follows:

0 -low potential;

1-high potential.

\subsubsection{Recreation Potential}

This criterion concerns the attractiveness of vegetation formations for recreational activities, such as hiking, nature photography and others. Vegetation plays an important role in the composition of rural landscape that can be evaluated for their bucolic and aesthetic aspects, with no acknowledgment of the role of farming. This is the expectation shared by foreign visitors staying generally for relatively short periods, who walk or go on bicycle or horse tours in this landscape. They can catch an impression based on the aesthetical and environmental quality of the landscape and appreciate natural and cultural heritage.

Since vegetation structure largely determines the aesthetic and environmental quality of the landscape, it plays a major role as a source of artistic inspiration and human wellbeing. On the other hand, the cultural heritage present in cork and holm oak montados does not only cover the tangible elements but also the intangible ones. Many montado intangible heritage values have a great potential for rural tourism development, like craftworks, gastronomy, local traditional and popular knowledge, legends and beliefs [44].

The installation of walking paths through montado landscapes will favor users' contacts with the multifunctional characteristics and activities of these agro-silvo-pastoral systems and, in particular, their natural and cultural heritage values [61,62]. Given the relative subjectivity that involves this criterion, it should be treated secondarily. In this study, the vegetation formations were classified as following:

0 -low potential;

1 -high potential.

\subsection{Integrated Analysis and GIS}

The selected criteria were applied to the land use patches of the Corine Land Cover Map, at level 5 and 1:10,000 scale. The use of GIS to analyze all the valued criteria, permitted the calculation of the VHV for more than 22,000 land cover patches. The criteria are briefly presented, as well as the scale of valorization used on the Table 2. 
Table 2. Vegetation Heritage Value (VHV): Criteria, weighting coefficients and evaluation classes.

\begin{tabular}{|c|c|c|c|}
\hline Criterion & Description & Weighting Coefficient & Number of Classes \\
\hline \multirow[t]{2}{*}{ Vegetation Structure } & $\begin{array}{l}\text { Horizontal Structure (1, } 2 \text { and } 3 \text { or more } \\
\text { species in consociation) }\end{array}$ & 4 & 3 \\
\hline & $\begin{array}{c}\text { Vertical structure (1, } 2 \text { or } 3 \text { vertical } \\
\text { stratus-herbaceous, scrubs or tree stratus) }\end{array}$ & 4 & 3 \\
\hline Tree density & $\begin{array}{l}\text { Refers to tree cover density }(<10 \% \text {; between } \\
\qquad 10-50 \% ;>50 \%)\end{array}$ & 3 & 3 \\
\hline Species rarity richness & $\begin{array}{l}\text { Number of rare species with } \\
\text { conservation status }\end{array}$ & 4 & 3 \\
\hline Phytocoenosis maturity & $\begin{array}{l}\text { Position of the formation in the vegetation } \\
\text { series: young, medium and mature }\end{array}$ & 3 & 3 \\
\hline Importance as ecological corridors & Connectivity and other ecological functions & 4 & 2 \\
\hline Historical record & Existence of historical research data & 1 & 2 \\
\hline $\begin{array}{l}\text { Scientific and } \\
\text { educational potential }\end{array}$ & $\begin{array}{c}\text { Concerns the vegetation formations with } \\
\text { high interest to future research and } \\
\text { educational activities }\end{array}$ & 3 & 2 \\
\hline Recreation potential & $\begin{array}{l}\text { Concerns the attractiveness of vegetation } \\
\text { formations to recreation activities }\end{array}$ & 1 & 2 \\
\hline
\end{tabular}

\section{Results and Discussion}

In regard to each of the criteria valued in the methodology it was considered in the case of the horizontal and vertical structure, presented in the Figure 2, that the most preserved vegetation patches are composed of the three strata (herbaceous, shrubs and trees), indicating generally their presence in the least human disturbance. This is quite important in fauna species that use these types of vegetation patches as habitat for food, shelter and reproduction functions.
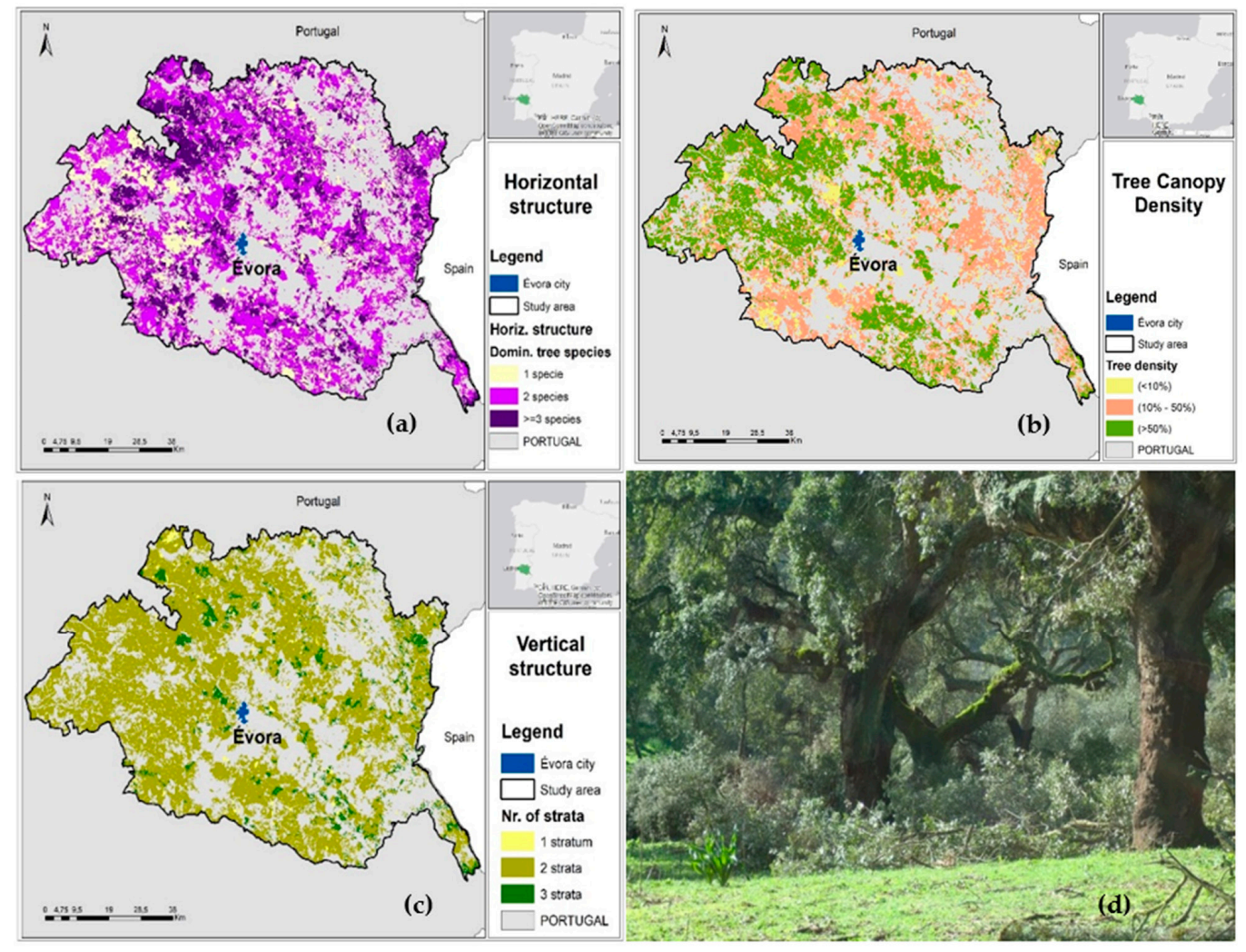

Figure 2. Horizontal and vertical vegetation structure; Tree cover/canopy density (author of maps $(\mathbf{a}, \mathbf{b}, \mathbf{c})$ and photo (d): T. Batista). 
The horizontal structure is connected with the number of dominant tree species. In the study areas there are two dominant Quercus species: The olm oak (Quercus rotundifolia) and the cork oak (Quercus suber). These are trees with hundred years old or more, protected by the Portuguese law, most of them relict from the previous Mediterranean forest, integrating nowadays the montado landscape.

The greater is the tree density, the greater the importance for conservation, as this density allows for the development of core species. Less tree density creates the porosity effect in the landscape, which promotes the exchange of energy and materials, resulting in the decrease in core species. In the Figure 2, we can see the location of the more and less dense vegetation patches.

In addition to the structural criteria previously mentioned, the existence of rare species was also considered. In the study area, these rare species are connected with the montado and pastural habitats.

The rare species or species with preservation status, that occur in the study area including Quercus suber and Quercus rotundifolia, are: Salix salviifolia subsp. australis, Thymus capitellatus, Thymus villosus, Narcisus bulbocodium, Malcolmia lacera, Ruscus aculeatus, Euphorbia transtagana Boiss, Narcisus fernandesii, Armeria pinifolia, Festuca duriotagana and Hyacinthoides vicentina spp. transtagana In the map bellow (Figure 3), we can identify the number of rare species per UTM grid $(1 \mathrm{~km} \times 1 \mathrm{~km})$ [63].
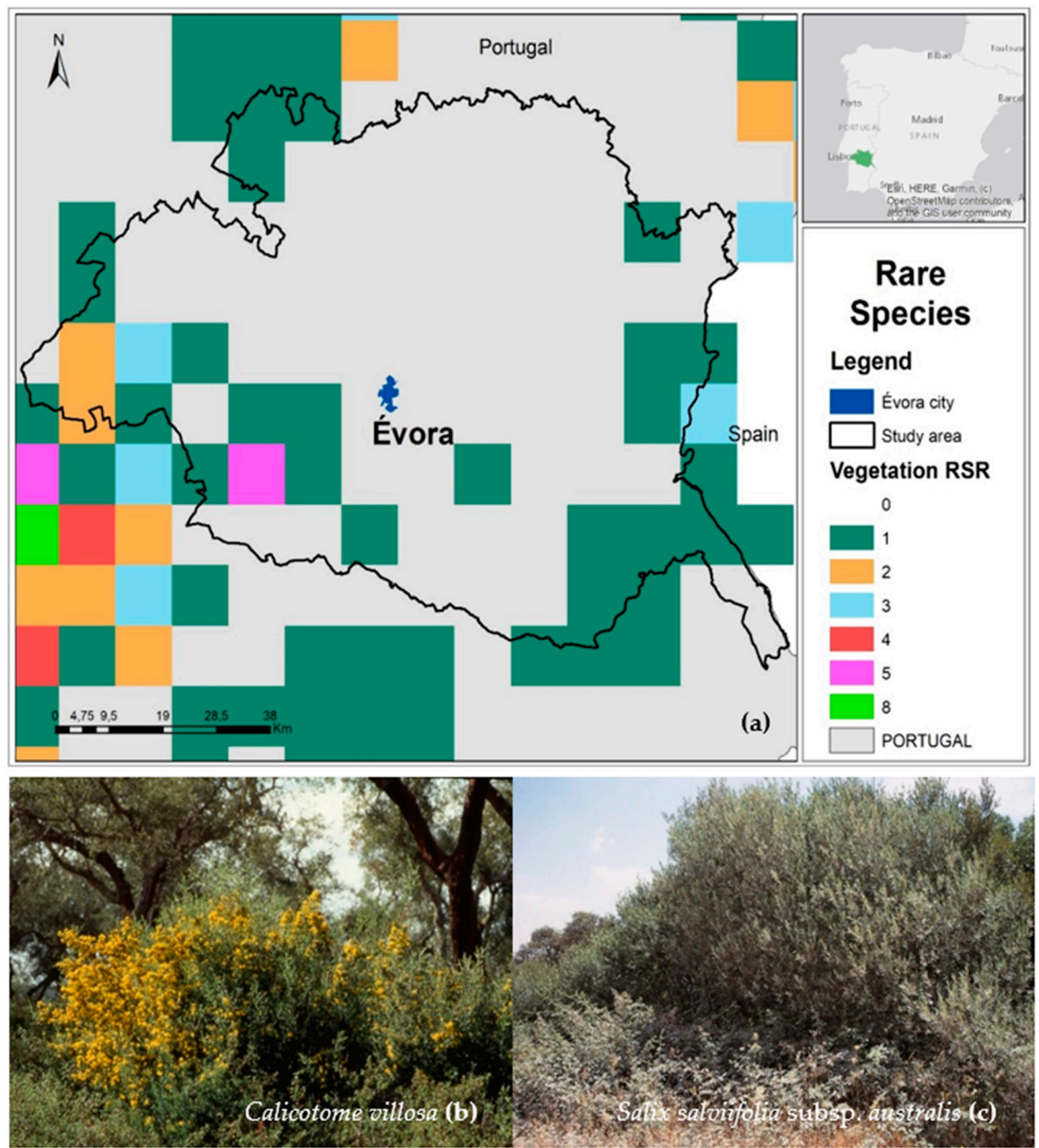

Figure 3. Rare vegetation species in the study area (Natura 2000 Annexes) (authors of the map (a): T. Batista, P. Mendes and C. P. Gomes) (author of the photos (b,c): J.M. de Mascarenhas). 
The phytocoenosis maturity criterion allows us to perceive the state of proximity to the climax situation wich is relevant in terms of conservation management. In the study area it was considered that the vegetation is mainly in two phytocenotic stages: low (the case of montados with crops) and medium (montados with high shrubs).

The vegetation corridors are also important landscape features, not only as habitat, but also due to the barrier effect and the fact that they favour the connectivity of fauna species. In this analysis, we mapped the most structured and lush vegetation river corridors, composed of arboreal and shruby vegetation (Figure 4).
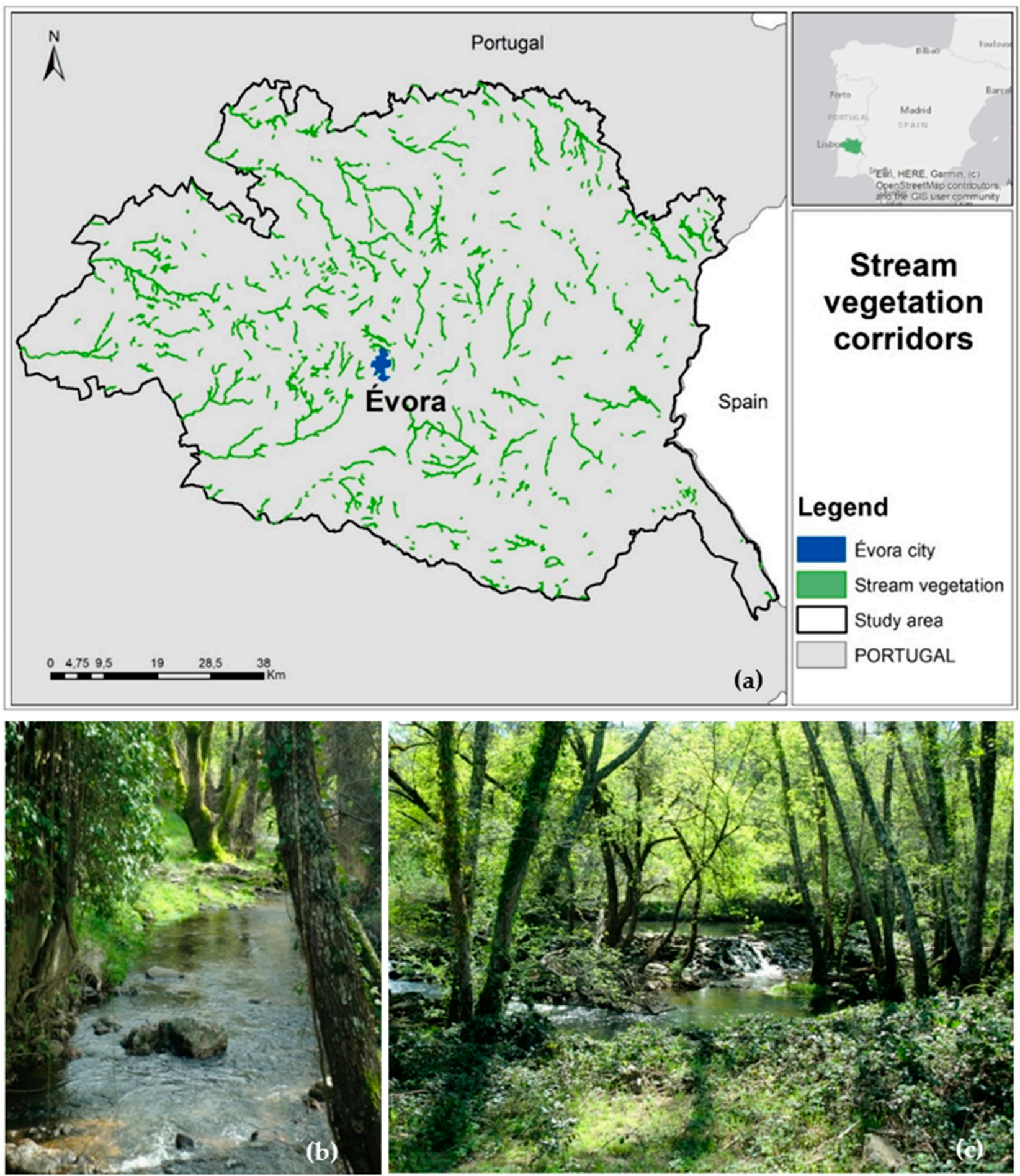

Figure 4. Vegetation stream corridors in the study area (author of the map (a) and photos (b,c): T. Batista). 
Non-intrinsic vegetation criteria were also applied, such as historical record, scientific and educational potential, interest and recreational potential interest, although these criteria has been assumed with lower weighting coefficients. The entire study area was considered to have high scientific and educational potential, high recreational interest, as well has a high historical record. As these criteria are often difficult to measure, a subjective appreciation was made based on the experience of one of the authors that is an expert in the vegetation of the region. Also, the authors considered that this was the necessary detail for this methodological essay approach.

The overall results obtained with the application of this method allowed the identification of the most important areas of vegetation heritage. From the $7500 \mathrm{~km}^{2}$ analyzed, $52 \%$ are natural and semi-natural areas, and of these, $18.8 \%$ have very high $\mathrm{VHV} ; 70.7 \%$ high VHV, and only 10.5\% have medium VHV (Figure 5).

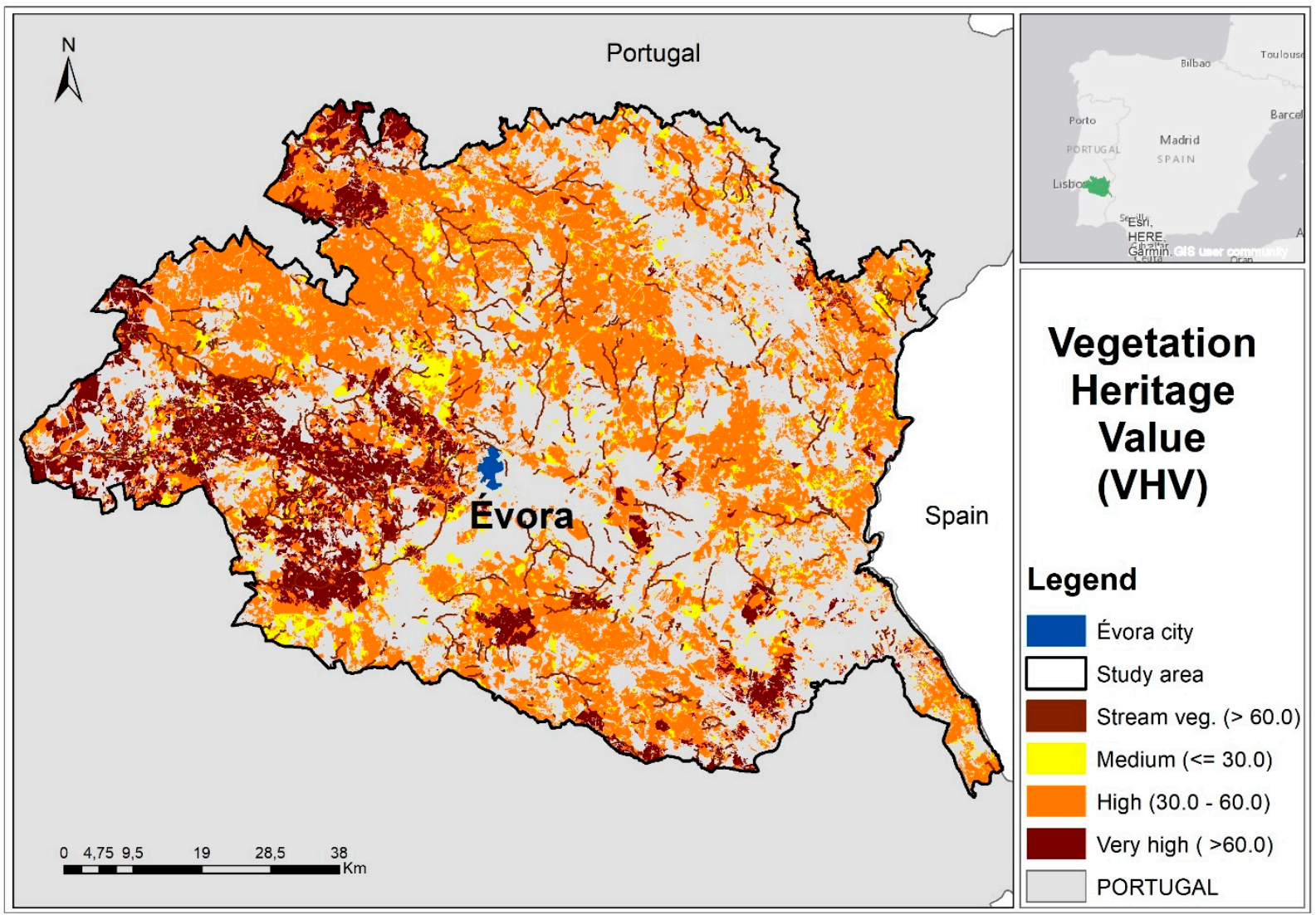

Figure 5. VHV map of the study area (author: T. Batista).

It is important to note that in the current protected areas (Natura 2000 sites of Monfurado, Cabrela and Cabeção) (Figure 6), the most significant part of very high VHV is enclosed; however the application of the method also revealed the existence, outside of these protected areas, of many important sites with very high and high vegetation heritage value.

We can also observe in the Figure 6 that the areas of special protection for birds (ZPEBird Directive), are actually linked to agricultural areas. These results are quite relevant, since they permitted the identification of the fundamental sites for the vegetation preservation. They show the strength of the methodology and the potential of its application in other areas.

These sites should deserve special attention by nature conservation authorities, including the regional and local ones, as well as by land managers and experts. 


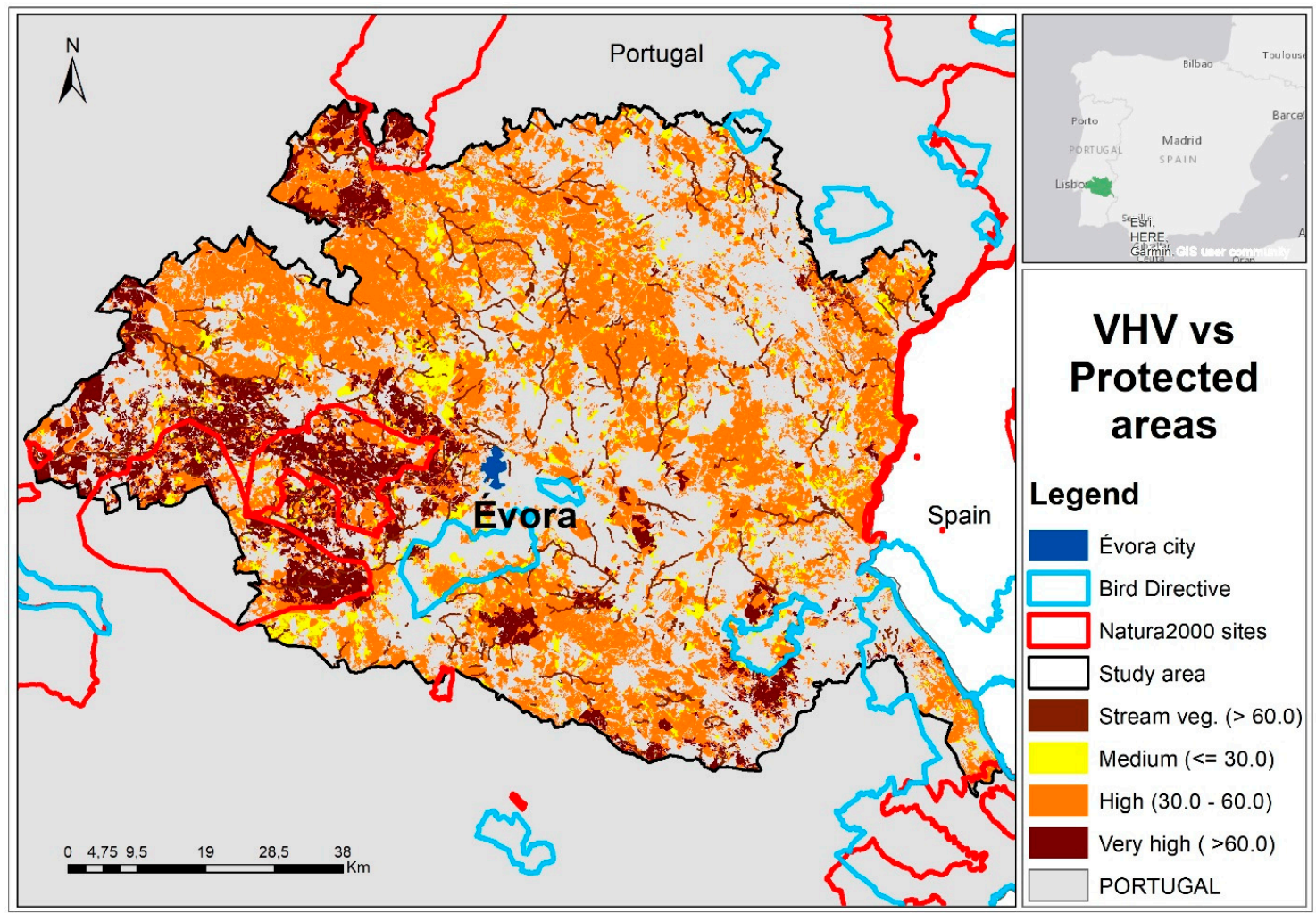

Figure 6. Interception of VHV map with the Protected Areas (Nature 2000 sites and Bird Directive sites) (author: T. Batista).

\section{Conclusions}

Although environmental values have been studied for a few decades, with many published works [29], the approach to vegetation in terms of heritage, particularly in an integrated framework, did not deserve due attention from the planning experts. By way of example, the Natural Heritage Vegetation Database for West Virginia (USA) was only made public in last decade [64]. Except for the administrative mechanisms, leading to the protection of certain plant assemblies or elements, such as historic gardens, monumental trees and rare species and formations [26], there are few methods developed for the heritage valuation of vegetation, from a practical perspective useful to conservation and land planning.

The presented essay shows that the method is very understandable and easy to apply, even in large areas (this case-study concerns a $7500 \mathrm{~km}^{2}$ area), and can be replicated in different regions and continents. This methodology allowed to identify potential areas for conservation purposes in the Alentejo Central region and it was observed that these areas correspond in several places with the current Natura 2000 sites. However, we are aware that its application implies a deep knowledge of the territory's vegetation and the existence of adequate cartography.

The method can still be improved, in particular, by introducing new evaluation criteria or new methods for selecting weighting coefficients. Other criteria of biological nature, but others in the fields of the human sciences (such as anthropology and other intangible heritage domains) may be considered in the assessment of vegetation heritage value.

Author Contributions: Conceptualization, T.B., J.M.d.M., P.M. and C.P.-G.; methodology, T.B., J.M.d.M., P.M. and C.P.-G.; validation, T.B., J.M.d.M., P.M. and C.P.-G.; formal analysis, T.B., J.M.d.M., P.M. and C.P.-G.; investigation, T.B., J.M.d.M., P.M. and C.P.-G.; writing-original draft preparation, T.B., J.M.d.M., P.M. and C.P.-G.; writing-review and editing, T.B., J.M.d.M., P.M. and C.P.-G.; supervision, T.B., J.M.d.M., P.M. and C.P.-G.; funding acquisition, T.B., J.M.d.M. and C.P.-G. All authors have read and agreed to the published version of the manuscript. Opinions and considerations are the sole responsibility of the authors who issues them. 
Funding: This work is funded by National Funds through FCT-FOUNDATION FOR SCIENCE AND TECHNOLOGY (Portugal) under the Projects UIDB/05183/2020 (MED) and UIDB/00057/2020 (CIDEHUS) and co-financed by the ERDF-EUROPEAN REGIONAL DEVELOPMENT FUND through the INTERREG V-A España-Portugal Program (POCTEP) 2014-2020, under the project 0753_CILIFO_5_E: Centro Ibérico para la Investigación y Lucha contra Incendios Forestales.

Institutional Review Board Statement: Not applicable.

Informed Consent Statement: Not applicable.

Data Availability Statement: MDPI Research Data Policies.

Acknowledgments: To MED, CIDEHUS and ICT Research Centres of the University of Évora, for institutional and administrative support, and to CIMAC-Intermunicipal Community of Alentejo Central for technical support.

Conflicts of Interest: The authors declare no conflict of interest.

\section{References}

1. Choay, F. L'Allégorie du Patrimoine; SEUIL: Paris, France, 1996.

2. UNESCO. World Heritage Centre's Natural Heritage Strategy; The UNESCO World Heritage Centre: Paris, France, 2006; Available online: https://whc.unesco.org/en/naturalheritagestrategy/ (accessed on 25 February 2021).

3. UNESCO. Convention Concerning the Protection of the World Cultural and Natural Heritage; UNESCO: Paris, France, 1972; Available online: https:/ / whc.unesco.org/archive/ convention-en.pdf (accessed on 25 February 2021).

4. Harrison, R. Beyond "Natural" and "Cultural" Heritage: Toward an Ontological Politics of Heritage in the Age of Anthropocene. Herit. Soc. 2015, 8, 24-42. Available online: https:/ / www.tandfonline.com/doi/full/10.1179/2159032X15Z.00000000036 (accessed on 25 February 2021). [CrossRef]

5. Audrerie, D. La Notion Et la Protection du Patrimoine; Presses Universitaires de France: Paris, France, 1997.

6. Leitão, L. Bridging the Divide between Nature and Culture in the World Heritage Convention: An Idea Long Overdue? Georg. Wright Forum 2017, 34, 195-210.

7. Mallarach, J.-M.; Verschuuren, B. Changing Concepts and Values in Natural Heritage Conservation: A View through IUCN and UNESCO Policies. In Values in Heritage Management: Emerging Approaches and Research Directions; Avrami, E., Macdonald, S., Mason, R., Myers, D., Eds.; The Getty Conservation Institute: Los Angeles, CA, USA, 2019; Available online: http:/ /www.getty. edu/publications / occasional-papers-3/part-two/10/ (accessed on 14 January 2021).

8. Batista, T.; de Mascarenhas, J.M.; Mendes, P.; Pinto-Gomes, C. Vegetation heritage value in Central Alentejo (Portugal) landscape: A GIS approach. In Proceedings of the Poster Presented at the IALE 2013 Congress, Manchester, UK, 9-12 September 2013.

9. Pinto-Correia, T.; Ribeiro, N.; Sa-Sousa, P. Introducing the montado, the cork and holm oak agroforestry system of Southern Portugal. Agrofor. Syst. 2011, 82, 99-104. [CrossRef]

10. Pinto-Correia, T.; Mascarenhas, J.M. Montado (Dehesa) of Portugal and Spain. In Threatened Landscapes Conserving Cultural Environments; Green, B., Vos, W., Eds.; Spon Press: London, UK; New York, NY, USA, 2001; pp. 100-101.

11. Capelo, S.; Barata, F.T.; de Mascarenhas, J.M. Why are cultural landscapes of various values? Thinking about heritage landscape evaluation and monitoring tools. J. Landsc. Ecol. 2011, 4, 5-17. [CrossRef]

12. Batista, T. Carta de ocupação e uso do solo do Distrito de Évora e Município de Sousel. In Map of Land Occupation and Use of the District of Évora and Municipality of Sousel; CIMAC: Évora, Portugal, 2011.

13. Guiomar, N.; Batista, T.; Fernandes, J.P.; Souto Cruz, C. Corine Land Cover Nível 5. Contribuição Para a Carta de Uso do Solo em Portugal Continental; AMDE (CIMAC): Évora, Portugal, 2009.

14. Capelo, S.; Barata, F.T.; de Mascarenhas, J.M. Caring about cultural landscapes: Looking for heritage evaluation and monitoring tools. In Proceedings of the International Conference 'Landscapes of everyday life', Séssion Plénière 3-Atelier C, Perpignan, France and Girona, Spain, 2011; Ministère de l'Ecologie, de l’Energie, du Développement Durable, et de l'Aménagement du Territoire: Paris, France, 2011; pp. 1-19.

15. Capelo, S.; de Mascarenhas, J.M.; Barata, F.T. Monitoring indicators as an important tool to assess the quality of heritage landscape along the time. Probl. Landsc. Ecol. 2011, 30, 241-248.

16. Pessoa, A.; Bettencourt, A.; Mascarenhas, J.M.; Matos, M.A.D.I.A. ALQUEVA-Declaração de Impacto Ambiental. Estudos de Impacto Ambiental do Empreendimento de Alqueva. In D.I.A. ALQUEVA-Environmental Impact Statement. Environmental Impact Studies of Alqueva Dam; DRENA-Empresa Geral de Fomento: Lisboa, Portugal, 1987.

17. Mascarenhas, J.M.; Soares, J.; Tavares da Silva, C. Proposta de Metodologia para Avaliação do Impacto de Barragens no Domínio Histórico-Arqueológico [Proposal of Methodology for Dams Impact Assessment in the Historical-Archaeological Domain]. Trab. Arqueol. Sul. 1986, 1, 7-16.

18. Malato-Beliz, J.V.; Mascarenhas, J.M.; Bettencourt, A.; Teles Grilo, J. Estudo de Impacte Ambiental na Vegetação Natural da Barragem de Alqueva. In Proceedings of the 1st International Symposium of Landscape Ecology, Évora, Portugal, 1996; Pinto-Gomes, C.J., Ed.; Universidade de Évora: Évora, Portugal, 1996; pp. 31-69. 
19. Mascarenhas, J.M. Évora: Archeology and Conservation of the surrounding landscape. In Cité et Térritoire; Clavel-Lévêque, M., Plana-Mallart, R., Eds.; Annales Littéraires de 1'Université de Besançon: Besançon, France, 1995; Volume 565, pp. 227-230.

20. Barata, F.T.; de Mascarenhas, J.M. Preservando a Memória do Território/Preserving the Land's Memories. O Parque Cultural de TouregaValverde/The Tourega-Valverde Cultural Park; Centro de Estudos de Ecossistemas Mediterrânicos-Universidade de Évora: Évora, Portugal, 2002.

21. Darvill, T.C. Ancient Monuments in the Countryside: An Archaeological Management Review; English Heritage: Swindon, UK, 1987.

22. Carver, M. On Archaeological Value. Antiquity 1996, 70, 45-56. [CrossRef]

23. Mason, R. Assessing Values in Conservation Planning: Methodological Issues and Choices. In Assessing the Values of Cultural Heritag; De La Torre, M., Ed.; The Getty Conservation Institute: Los Angeles, CA, USA, 2002; pp. 5-30.

24. Tengberg, A.; Fredholm, S.; Eliassona, I.; Knez, I.; Saltzman, K.; Wetterberg, O. Cultural ecosystem services provided by landscapes: Assessment of heritage values and identity. Ecosyst. Serv. 2012, 2, 14-26. [CrossRef]

25. Fredheim, L.H.; Khalaf, M. The significance of values: Heritage value typologies re-examined. Int. J. Herit. Stud. 2016, $22,466-481$. [CrossRef]

26. Dubost, F. Vert Patrimoine, La Constitution d'un Nouveau Domaine Patrimonial; La Maison des Sciences de l'Homme: Paris, France, 1994.

27. Balmer, J.; Whinam, J.; Kelman, J.; Kirkpatrick, J.B.; Lazarus, E. A Review of the Floristic Values of the Tasmanian Wilderness World Heritage Area; Nature Conservation Report No. 2004/3; Department of Primary Industries Water and Environment: Hobart, Australia, 2004.

28. Ejrnæs, R. Valuation of Habitats for Conservation: Concepts, Methods and Applications; Nordic Council of Ministers: Copenhagen, Denmark, 2005.

29. O'Neill, J.; Holland, A.; Light, A. Environmental Values; Routledge: Abingdon, UK; New York, NY, USA, 2008.

30. Schultze, J.; Gärtner, S.; Bauhus, J.; Meyer, P.; Reif, A. Criteria to evaluate the conservation value of strictly protected forest reserves in Central Europe. Biodivers. Conserv. 2014, 23, 3519-3542. [CrossRef]

31. Kosanic, A.; Anderson, K.; Frère, C.H.; Harrison, S. Regional vegetation change and implications for local conservation: An example from West Cornwall (United Kingdom). Glob. Ecol. Conserv. 2015, 4, 405-413. [CrossRef]

32. Davis, M.; Head, N.J.; Myers, S.C.; Moore, S.H. Department of Conservation Guidelines for Assessing Significant Ecological Values; New Zealand Department of Conservation: Wellington, New Zealand, 2016.

33. Capmourteres, V.; Anand, M. Conservation value: A review of the concept and its quantification. Ecosphere 2016, 7, e01476. Available online: https:/ / esajournals.onlinelibrary.wiley.com/doi/epdf/10.1002/ecs2.1476 (accessed on 6 January 2021). [CrossRef]

34. Gastón, A.; Blázquez-Cabrera, S.; Ciudad, C.; Mateo-Sánchez, M.C.; Simón, M.A.; Saura, S. The role of forest canopy cover in habitat selection: Insights from the Iberian lynx. Eur. J. Wildl. Res. 2019, 65. [CrossRef]

35. Batista, T.; de Mascarenhas, J.M.; Mendes, P.; Mantas, V. Heritage Landscapes in Évora surroundings: A GIS approach. In Proceedings of the 27th ECLAS Conference 'Cultural Landscape', Istambul, Turkey, 2010; Yildizci, A.C., Ed.; ECLAS and ITU: Istambul, Turkey, 2010; pp. 791-802.

36. Schapper, J.A. Criteria for the Evaluation of Landscape as Heritage. Ph.D. Thesis, School of Environmental Planning, Faculty of Architecture and Planning, The University of Melbourne, Melbourne, Australia, 1994.

37. Bruns, D.; Green, B.H. Identifying threatened, valued landscapes. In Threatened Landscapes, Conserving Cultural Environments; Green, B., Vos, W., Eds.; Spon Press: London, UK, 2001; pp. 119-127.

38. Lowenthal, D. Natural and cultural heritage. Int. J. Herit. Stud. 2005, 11, 81-92. [CrossRef]

39. Luginbühl, Y. Paysage et identification, qualification et objectifs de qualité. In Paysage et Développement Durable: Les Enjeux de la Convention Européenne du Paysage; Dejeant-Pons, M., Buergi, E., Eds.; Conseil de l'Europe: Strasbourg, France, 2006; pp. 107-125.

40. Stephenson, J. The Cultural Values Model: An integrated approach to values in landscapes. Landsc. Urban Plan. 2008, 84, 127-139. [CrossRef]

41. Butler, A. Dynamics of integrating landscape values in landscape character assessment: The hidden dominance of the objective outsider. Landsc. Res. 2016, 41, 239-252. [CrossRef]

42. Taylor, K. Cultural landscape meanings and values. In Research in Landscape Architecture: Methods and Methodology; Van Den Brink, D., Bruns, A., Tobi, H., Bell, S., Eds.; Routledge: New York, NY, USA, 2017; pp. 211-234.

43. de Mascarenhas, J.M.; Barata, F.T.; Capelo, S. Intangible heritage and cultural landscapes: Improving an evaluation system. In Sharing Cultures 2017, Proceedings of the 5th International Conference on Intangible Heritage, Barcelos, Portugal, 2017; Lira, S., Amoêda, R., Pinheiro, C., Eds.; Green Lines Institute for Sustainable Development: Barcelos, Portugal, 2017; pp. 265-273.

44. Batista, T.; de Mascarenhas, J.M.; Mendes, P.; Carriço, C. Montado intangible heritage in Southern Portugal. In Sharing Cultures 2017, Proceedings of the 5th International Conference on Intangible Heritage, Barcelos, Portugal, 2017; Lira, S., Amoêda, R., Pinheiro, C., Eds.; Green Lines Institute for Sustainable Development: Barcelos, Portugal, 2017; pp. 55-67.

45. Harmon, D.; Putney, A. (Eds.) The Full Value of Parks: From Economics to the Intangible; Rowman \& Littlefield Publishers: Lanham, MD, USA, 2003.

46. Taylor, K. The challenges of the cultural landscape construct and associated intangible values in an Asian context. In Asian Heritage Management: Contexts, Concerns, and Prospects; Silva, K.P., Chapagain, N.K., Eds.; Routledge: Abingdon, UK, 2013; pp. 189-211. 
47. Costa, J.C.; Neto, C.; Aguiar, C.; Capelo, J.; Espirito-Santo, M.D.; Honrado, J.; Lousã, M. Vascular plant communities in Portugal (Continental, the Azores and Madeira). Glob. Geobot. 2012, 2, 1-180.

48. Ramírez, B.; Fernández, L.; Cabezas, J.; Jiménez, A.; Mendes, P.; Vila-Viçosa, C.; Pinto-Gomes, C. Bioclimatologia, Biogeografia e Vegetação Potencial na área OTALEX C. In 2013 OTALEX C: Resultados del Proyecto; Ceballos, F., Puerto, M., Batista, T., Carriço, C., Eds.; DGTOTU-Junta de Extremadura: Mérida, Spain, 2013; pp. 73-82.

49. Odum, E.P. The strategy of ecosystem development. Science 1969, 164, 262-270. [CrossRef]

50. Gehlbach, F.R. Investigation, Evaluation, and Priority Ranking of Natural Areas. Biol. Conserv. 1975, 8, 79-88. [CrossRef]

51. Batista, T.; Cavaco, J.; Mendes, P.; Vila-Viçosa, C.; Penas, A.; Río, S.; Cabezas, J.; Fernández-Pozo, L.; Arancibia, N.; Pinto-Gomes, C. Conservation status of vegetation in the north and central area of Pardiela river basin (Évora, Portugal). Acta Bot. Gall. Bot. Lett. 2012, 159, 177-185. [CrossRef]

52. Forman, R.; Godron, M. Landscape Ecology; John Wiley and Sons: New York, NY, USA, 1986.

53. Hoechstetter, S. Enhanced Methods for Analyzing Landscape Structure: Landscape Metrics for Characterizing Three-Dimensional Patterns and Ecological Gradients; Rhombos-Verlag: Berlin, Germany, 2009.

54. Farina, A. Principles and Methods in Landscape Ecology; Springer: Dordrecht, The Netherlands, 2006.

55. Bennett, G.; Wit, P. The Development and Application of Ecological Networks: A Review of Proposals, Plans and Programmes; AIDEnvironment: Amsterdam, The Netherlands, 2001.

56. Jongman, R. Ecological networks are an issue for all of us. J. Landsc. Ecol. 2008, 1, 7-13. [CrossRef]

57. Eberhardt, R.; Foster, D.R.; Motzkin, G.; Hall, B. Conservation of changing landscapes: Vegetation, land-use history, and fire on Cape Cod National Seashore. Ecol. Appl. 2003, 13, 68-84. [CrossRef]

58. Margules, C.; Usher, M.B. Criteria used in assessing wildlife conservation potential: A review. Biol. Conserv. 1981, 21, 79-109. [CrossRef]

59. Usher, M. Wildlife Conservation Evaluation: Attributes, Criteria and Values; Chapman and Hall: London, UK, 1986.

60. Goldsmith, F.B. Evaluating Nature. In Conservation in Perspective; Warren, A., Goldsmith, F.B., Eds.; John Wiley: Chichester, UK, 1983; pp. 233-245.

61. Carriço, C.; Batista, T.; De Mascarenhas, J.M.; Mendes, P. The Montado Great Route Sustainable Tourism: Threats and opportunities. In Proceedings of HERITAGE 2018 -6th International Conference on Heritage and Sustainable Development; Amoêda, R., Lira, S., Pinheiro, C., Zaragoza, J.M.S., Serrano, J.C., Carrillo, F.G., Eds.; Green Lines Institute for Sustainable Development: Barcelos, Portugal, 2018; Volume 2, pp. 1681-1688.

62. Surová, D.; Pinto-Correia, T. Use and assessment of the 'new' rural functions by land users and landowners of the Montado in southern Portugal. Outlook Agric. 2009, 38, 189-194. [CrossRef]

63. Sociedade Portuguesa de Botânica. Flora-On: Flora de Portugal Interactiva. 2014. Available online: https://flora-on.pt (accessed on 15 February 2021).

64. Vanderhorst, J.; Byers, E.A.; Streets, B. Natural Heritage Vegetation Database for West Virginia. Biodivers. Ecol. 2012, 4, 440. [CrossRef] 